\title{
Addressing management questions for Ngorongoro Conservation Area, Tanzania, using the SAvannA modelling system
}

\author{
Randall B. Boone*, Michael B. Coughenour*, Kathleen A. Galvin ${ }^{*} \dagger$ and James E. Ellis* \\ ${ }^{*}$ Natural Resource Ecology Laboratory and the $\dagger$ Department of Anthropology, Colorado State University, Fort Collins, Colorado, \\ 80523-1499, USA
}

\begin{abstract}
Ngorongoro Conservation Area (NCA), in northern Tanzania, is a multiple-use area of importance to Maasai pastoralists and wildlife conservation. We adapted the SAVANNA modelling system to the NCA, creating an Integrated Management and Assessment System that allows users to assess responses to alternative management actions. We used the system to conduct fifteen experiments reflecting potential management questions. Results suggest that: the distribution of rainfall throughout the year may have a greater impact on the ecosystem than its quantity; cattle may be near a carrying capacity determined not by forage limitations but because of disease risks; increasing survival and reducing disease in livestock yields greater returns than increasing birth rates; allowing livestock to graze in areas where they are currently excluded may lead to a slight increase in livestock populations, but sometimes leads to large declines in wildlife populations; few ecosystem effects were noted when households and cultivation were allowed to grow at 3\% per year for 15 years; and when up to $5 \%$ of the study area was in cultivation, there were declines $\leq 16 \%$ in livestock and wildlife populations, except for elephants, which declined by $48 \%$. Users may modify our experiments using tools we have developed, or address other NCA management questions.
\end{abstract}

Key words: livestock, Maasai, Ngorongoro, Savanna, simulation, wildlife

Correspondence: Dr Randall B. Boone, A215 NESB, Natural Resource, Ecology Laboratory, Colorado State University, Fort Collins, CO 80523-1499, USA. Tel.: +1970 4911964;

Fax: +1970 491 1965; E-mail: rboone@nrel.colostate.edu

\section{Résumé}

L'Aire de Conservation du Ngorongoro (NCA), au nord de la Tanzanie, est une aire multi-usages importante pour les pasteurs Masaï et pour la conservation de la faune sauvage. Nous avons adapté le modèle SAVANNA à la NCA, créant un Système intégré de gestion et d'évaluation qui permet à ses utilisateurs d'évaluer les réponses à différentes activités de gestion. Nous nous sommes servis du modèle pour mener 15 expériences reflétant différents problèmes de gestion possibles. Les résultats suggèrent que: la distribution des chutes de pluies tout au long de l'année peut avoir un plus grand impact sur l'écosystème que leur quantité; le bétail peut être proche de la charge pondérale, déterminée non par la disponibilité de la nourriture, mais par les risques de maladies; augmenter la survie et réduire les maladies du bétail donne de meilleurs résultats que d'augmenter la natalité; permettre au bétail de pâturer dans des zones d'où il est actuellement exclu peut augmenter légèrement les populations de bétail, mais cela entraîne parfois un déclin important des populations sauvages; on a remarqué peu d'effets sur l'écosystème lorsque les foyers et leurs cultures ont été autorisés à croître de $3 \%$ par an pendant 15 ans; et lorsque $5 \%$ de l'aire étudiée ont été mis en culture, on a constaté une diminution $\leq 16 \%$ des populations de bétail et de faune sauvage, sauf des éléphants qui ont diminué de $48 \%$. Les utilisateurs peuvent modifier nos expériences en se servant des outils que nous avons mis au point, ou aborder d'autres problèmes de gestion de la NCA.

\section{Introduction}

Ngorongoro Conservation Area (NCA), in north-eastern Tanzania (Fig.1), was created in 1959 explicitly as a 


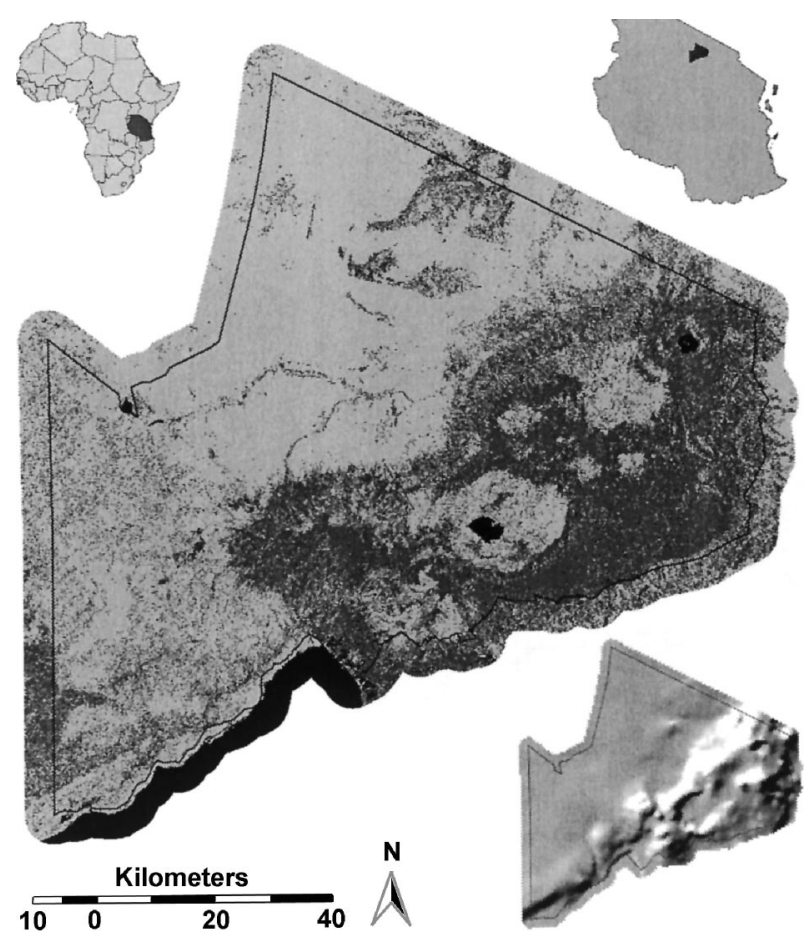

Fig 1 The study area, Ngorongoro Conservation Area,Tanzania. Areas in dark grey are forest or dense shrub, light grey are grassland or woodland, and black are water. Ngorongoro Crater is in the south-central portion of the area, with Lake Magadi on the crater floor. Insets depict the location of the study area in Africa and Tanzania (top) and the general topography of the site (bottom), showing the highlands to the south-east and plains to the north-west

multiple-use area, with both wildlife conservation and human welfare to be considered in management decisions. The NCA is home for more than 50,000 Maasai pastoralists and their livestock (Kijazi et al., 1999), an increasing human population (10,633 in 1954 to 51,621 in 1999; reviewed in NCAA, 1999), and cultivation first outlawed in 1975, and then reinstated in 1992 (Perkin, 1997; NCAA, 1999). The land-use practices of the Maasai are changing (McCabe, 1997) and their food security is being threatened (Galvin et al., in press). Maasai families are becoming more sedentary, for example (Homewood \& Rodgers, 1991; McCabe, 1997).

The Ngorongoro Conservation Area Authority has the complex task of balancing the competing needs of users. In the simplest of examples, considering the well-being of the Maasai is explicitly a part of the Authority's mandate (Thompson, 1997), however, human population increases may reduce wildlife populations, and tourists prefer views that do not include villages. In contrast, tourist visits can have deleterious effects on conservation (Western \& Gichohi, 1993). We developed an Integrated Modelling and Assessment System (IMAS) for the NCA that includes ecosystem and socioeconomic modelling, spatial analyses, and field work to help assess management decisions. Here we review our ecosystem modelling efforts and present results for potential management questions. While demonstrating the utility of ecological modelling in African savannas (as others have, e.g. Harris \& Fowler, 1975; Norton-Griffiths, 1979; Toxopeus et al., 1994; Hilborn et al., 1995; Gignoux et al., 1996; Wiegand et al., 1998), we also review some of the complexities facing managers, and some potential solutions. The questions we address include: changes in livestock stocking rates; benefits from improved veterinary practices; the effects of access by livestock to areas where they are now excluded; adding and removing water sources; effects of human population growth; and effects of cultivation.

\section{Methods}

\section{SAVANNA modelling system}

Evaluating how ecosystem components may change in response to management requires a model that is complex enough to represent those management actions fairly (Hilborn et al., 1995); we use the SAvANNA modelling system. The development of SAvanna began more than 15 years ago, to support research in the Turkana District of Kenya (Coughenour et al., 1985). Improvements to the model were made in subsequent applications (e.g. Coughenour, 1992; Buckley et al., 1993; Coughenour \& Ellis, 1993; Coughenour \& Singer, 1996; reviewed in Ellis \& Coughenour, 1998). SAVANNA has been used, for example, to: understand the carrying capacity of livestock in Australian grazing lands (Ludwig \& Tongway, 1997); manage elk in the Rocky Mountain (Weisberg, 2000) and Yellowstone National Parks of the USA (Coughenour \& Singer, 1996); evaluate carrying capacity for livestock and wildlife of Kruger National Park, South Africa (Kiker, 1998); and address management issues for Mongolian pastoralists' cattle, sheep and horses (Christensen et al., 1999).

SAVANNA is a series of interconnected Fortran computer programs that model primary ecosystem interactions in arid and semi-arid landscapes. SAvAnNA is spatially explicit, and models landscapes using a gridded system 
of cells. The model predicts water availability to plants using rainfall and soil properties for each of the cells. Based upon water, light and nutrient availability, primary production is calculated for plant functional groups, using process-based methods (Lambin, Rounsevell \& Geist, 2000). Plant populations are calculated from primary production. At each weekly time-step plants may, for example: produce seeds that become established; grow into older age classes; out-compete other plant functional groups; or die.

A habitat suitability index (see Van Horne \& Wiens, 1991) is calculated for each cell, at weekly intervals and for each animal functional group, based upon forage quality and quantity, slope, elevation, cover and the density of herbivores. Individuals in the population are distributed on the landscape based upon these indices. Animals will feed upon the available vegetation, depending upon dietary preferences and consumption rates. The energy gained is reduced by energy costs associated with basal metabolism, gestation and lactation. Net energy remaining goes toward weight gain, with weights reflected in condition indices. Summaries of the status of vegetation, herbivores, climate, and humans are produced at monthly intervals (see Ellis \& Coughenour, 1998, for more detail).

\section{Adapting SAvanna to Ngorongoro Conservation Area}

Functional groups. When adapting SAvanNa to a new ecosystem, specific functional groups of plants and animals are defined, depending upon the management questions of interest. For NCA, we defined seven plant functional groups: (1) palatable grasses, (2) palatable forbs, (3) unpalatable herbaceous plants, (4) palatable shrubs, (5) unpalatable shrubs, (6) evergreen forests, and (7) deciduous woodlands. Here the term palatable reflects a general acceptance by herbivores; 'evergreen forests' are primarily the forests of Ngorongoro Highlands; and 'deciduous woodlands' are primarily acacia woodlands.

Seventeen herbivore functional groups were defined, including some species split into resident and migratory populations, or populations within ('crater') and outside ('area') Ngorongoro Crater. The herbivores used were: cattle, goats, and sheep (1-3); migratory and resident wildebeest (Connochaetes taurinus, Burchell), zebra (Equus burchelli, Gray), and grazing antelope (4-9); crater and area African buffalo (Syncerus caffer, Sparrman) and browsing antelope (10-13); elephants (Loxodonta africana, Blumenback) (14); rhinoceros (Diceros bicornis, L) (15); giraffe (Giraffe camelopardalis, L) (16); and warthog (Phacochoerus aethiopicus, Pallas) (17). Three groups of antelopes (i.e. resident grazing, and crater and area browsing antelopes) included multiple species, and migratory antelopes areThomson's gazelles (Gazella thomsoni, Günther).

Geographic layers. SAvanna uses geographical layers describing elevation, slope, aspect, soils, vegetation, water sources and restrictions upon animal movements. Topographic information for NCA (plus a 5-km buffer around the area) was calculated from a digital elevation model produced by the US Geological Survey (USGS). All geographical data were generalized to two resolutions, $1 \mathrm{~km} \times 1 \mathrm{~km}$ and $5 \mathrm{~km} \times 5 \mathrm{~km}$ cells. Soils came from the map produced by the Food and Agriculture Organization, and recoded by USGS (USGS, 1997). Land cover was mapped by M. Kalkhan (Natural Resource Ecology Laboratory, Colorado State University, USA) using Landsat satellite data and existing vegetation maps. Water sources for NCA were based primarily upon Aikman \& Cobb (1997), and restrictions upon grazing were extracted from Machange (1997) and other authors in Thompson (1997), and from reviews by experts.

Parameterizing the model. A suite of parameters too numerous to cite were set in the model, based upon a literature review that included more than 100 sources (some are cited below), previous SAvANNA applications (e.g. Coughenour, 1992; Kiker, 1998), fieldwork associated with this project, and expert opinion. As an indication of the process-orientated nature of SAVANNA, the model includes plant growth and population parameters, such as specific leaf weight and fine-root death rate due to water stress. Parameters describe the diets of herbivores, energy costs, birth and death rates, and habitat relationships (Boone \& Krohn, 2000). In the model, 105,202 cattle, 130,000 goats and 60,000 sheep were placed in the system (Machange, 1997; Thompson, 1997). Approximately 900,000 wildebeest inhabited the Serengeti Ecosystem in the late 1990s (Mduma et al., 1998), of which about $50 \%$ spent some portion of their year on NCA (A.R.E. Sinclair, pers. comm.). These 450,000 wildebeest were joined by 66,000 zebra and buffalo, 156,000 grazing antelope, 14,000 browsing antelope, 300 elephants, 14 rhinos and 1700 giraffes. Lastly, soil and climate data 
were incorporated into the model. Climate data were available from 1963 to 1992, and we selected data for a 15-year period (1973-1988) to model. Note however, that data on human and herbivore populations represent conditions from the late 1990s, and thus the simulations do not represent a particular period and in figures the years are designated $1-15$.

Model adjustment and assessment. Model control parameters were adjusted until values from the literature for measures such as plant allometrics (e.g. Coughenour, 1985; Hodgkinson et al., 1989; Coughenour et al., 1993; Tewari, 1996), standing plant biomass (e.g. NdawulaSenyimba, 1972; Stronach \& McNaughton, 1989; Mwalyosi, 1992; Murray, 1995) and herbivore populations (e.g. Homewood \& Rodgers, 1991; Campbell \& Borner, 1995; Runyoro et al., 1995; Boshe, 1997; Machange, 1997; McCabe, 1997) were similar to those modelled. The resulting model was a preliminary 'control', for use in comparisons with the results of model experiments. Green biomass responses in SAVAnNa were compared to Normalized Difference Vegetation Indices created by the Global Land 1-km AVHRR program (USGS, 1998), which represents plant biomass derived from satellite images. From these comparisons, we judged the model to be representing vegetation biomass reasonably well (e.g. $r \geq 0.60, P<0.01)$. Detailed assessments were made by comparing biomass and greenness estimates from SAVANNA to long-term field vegetation data collected by the Ngorongoro Ecological Monitoring Program (Runyoro, 1998), for sixteen sites within the NCA. Vegetation biomass was being underestimated $(r=0.34$, $P>0.1)$ due to our setting vegetation disturbance levels and the rate of leaf-fall to litter too high, whereas phenology was being modelled reasonably well $(r=0.72, P$ $<0.001)$. We modified the simulation, yielding the final control model. As an integrative model, SAvanNa results can be challenging to assess, so the responses of experts were critical in judging the success of the modelling effort. More than 100 experts in various fields have seen the results, with favourable feedback. In particular, 26 East African scientists and managers, including ecologists working in NCA, have had in-depth exposure to the model results during 3- to 5-day training workshops.

Simulating management scenarios. A series of experiments was conducted and compared to the control model. The experiments were selected to both address potential management questions and to demonstrate the flexibility of the IMAS system. For brevity, the conditions of the individual experiments will be introduced as results are reported.

\section{Results}

\section{Drought}

We first explored how drought would affect range condition, livestock and wildlife. The normal precipitation during years 9 and 10 (i.e. 1983 and 1984) was reduced by $50 \%$ (Fig. $2 \mathrm{a}$ ), the model experiment was run, and the results compared to those from the control model. Vegetation biomass decreased during the simulated drought, as expected, with shrubs dropping from 150 to $100 \mathrm{~g} \mathrm{~m}^{-2}$ (averaged over the entire study area) (Fig. 2b). Green leaf biomass declined by one-third during the dry season. Annual net primary productivity for palatable grasses decreased by $50 \mathrm{~g} \mathrm{~m}^{-2}$ (Fig. 2c). The number of cattle declined by about 20,000 animals (19\%).

Scientists predict changes in the distribution of rainfall in response to global climate change (e.g. Hall et al., 1995; Groisman et al., 1999). We modified the annual temporal distribution of rainfall in the NCA by reducing the amount in the five wettest months (December-April) by $1 \%$, and adding this amount to the five driest months (May-September) (Fig. 2d); the total precipitation remained unchanged. When simulated, large increases in dry-season green biomass were observed (e.g. Fig. 2e versus 2f), similar to Hall et al. (1995) for dry savannas. Wildlife populations increased markedly, and increases in livestock occurred, although the increases were moderated by increased tick-borne disease.

\section{More livestock}

The number of livestock in the NCA has been relatively stable over the last 40 years (but the number of people has been increasing) (Kijazi et al., 1997; McCabe, 1997). There are ongoing efforts, however, to increase the number of livestock (C. Sorensen, Danish International Development Assistance, pers. comm.). We assessed the potential effects of this by conducting simulations with $50 \%$ more livestock than in the control. The increased livestock populations remained relatively stable until a dry period occurred in year 8 , and then declined (Fig. 3a). Cattle populations, body conditions, and offtake 
(a)
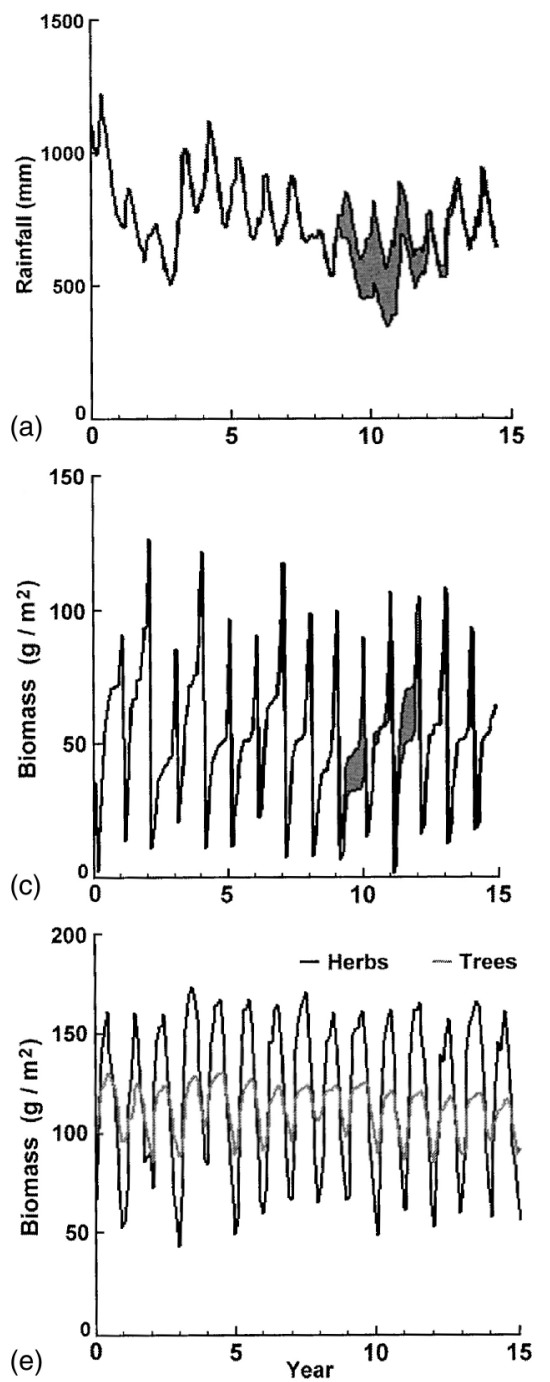
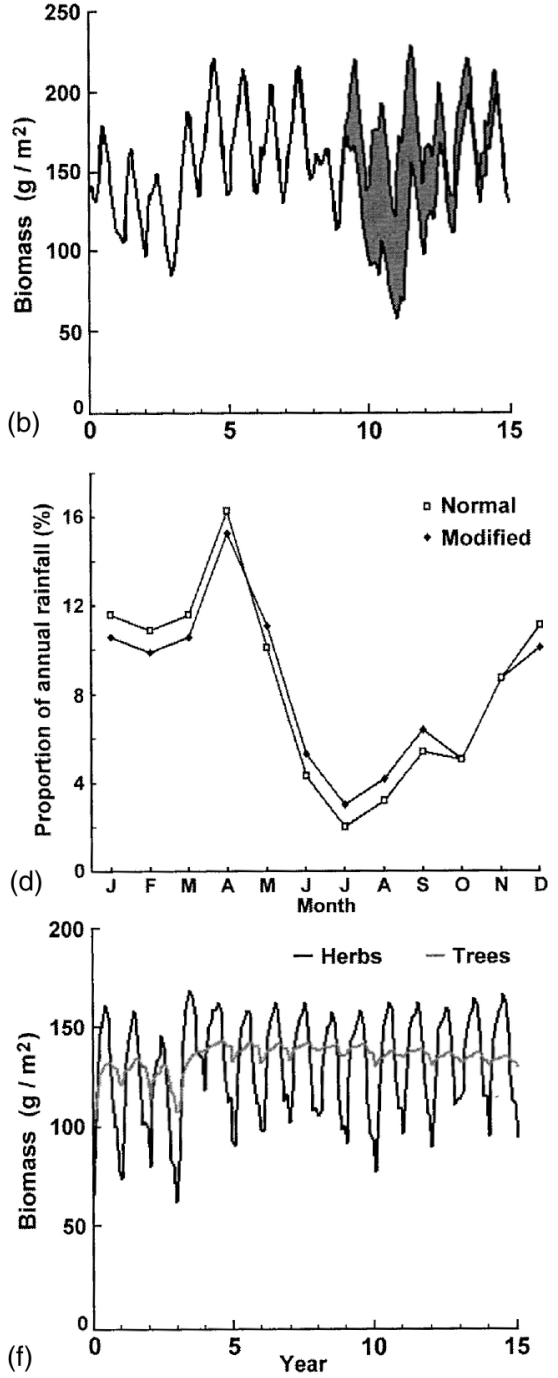

Fig 2 Experiments addressing changes in rainfall. A drought was simulated by making rainfall in year 9 and 10 , of $50 \%$ of normal ((a), with the shaded area highlighting the decrease in rainfall), which reduced shrub biomass during that period (b) and accumulated net primary productivity of palatable grasses (c). Moving $1 \%$ of the annual rainfall from the five wettest months to the five driest (d) dramatically improved range condition and increased herbivore populations. Comparing the standing biomass of herbs and trees in the control model (e) and with rainfall redistributed (f) demonstrates the improved range condition
(Figs $3 \mathrm{~b}, \mathrm{c}$ ) declined sharply because the cattle were restricted to the midlands and highlands during the wet season, avoiding the NCA plains because wildebeest calves can transmit malignant catarrhal fever to the cattle (McCabe, 1995).

In another experiment, we held livestock populations high $(+50 \%)$ and constant, to: (1) represent importation of livestock by some group (e.g. donor or governmental agency) that might seek to maintain livestock at a given level, and (2) make changes in vegetation and wildlife populations easier to interpret. The leaf biomass of palatable grass decreased about $15 \%$, unpalatable herbaceous biomass increased by 10\% (Fig. 3d), and most wildlife populations declined (e.g. Fig. 3e). Some wildlife popula- tions, such as rhinoceros inhabiting the Ngorongoro Crater, did not decline because livestock are not allowed to graze in the craters (Fig. 3f).

\section{Improved veterinary practices}

Losses of livestock due to disease can be extreme in the NCA (McCabe, 1995, 1997; Rwambo et al., 1999). Efforts are underway to improve the survival of the livestock (C. Sorensen, pers. comm.). We investigated the effects of improved veterinary care by modifying the population parameters in SAVANNA. Livestock populations were not allowed to increase indefinitely; the experiments just described explored effects of elevated livestock numbers. 
Fig 3 Experiments increasing the number of livestock. When livestock populations were increased by $50 \%$, each declined during a dry period, with cattle declining markedly (a). Animal conditions declined as well (b), but returned to high levels in a densitydependent response. SAVANNA reports results spatially as well, with the large decline in accumulated offtake (c) as an example. If livestock populations are increased by $50 \%$ and held constant, range condition declines, as demonstrated by an increase in unpalatable herbaceous plants ((d), with the grey area highlighting the increase in biomass). Wildlife populations, such as elephants and warthogs (e), declined as well, unless relatively isolated from changes in livestock populations, as rhinoceros were in Ngorongoro Crater (f)
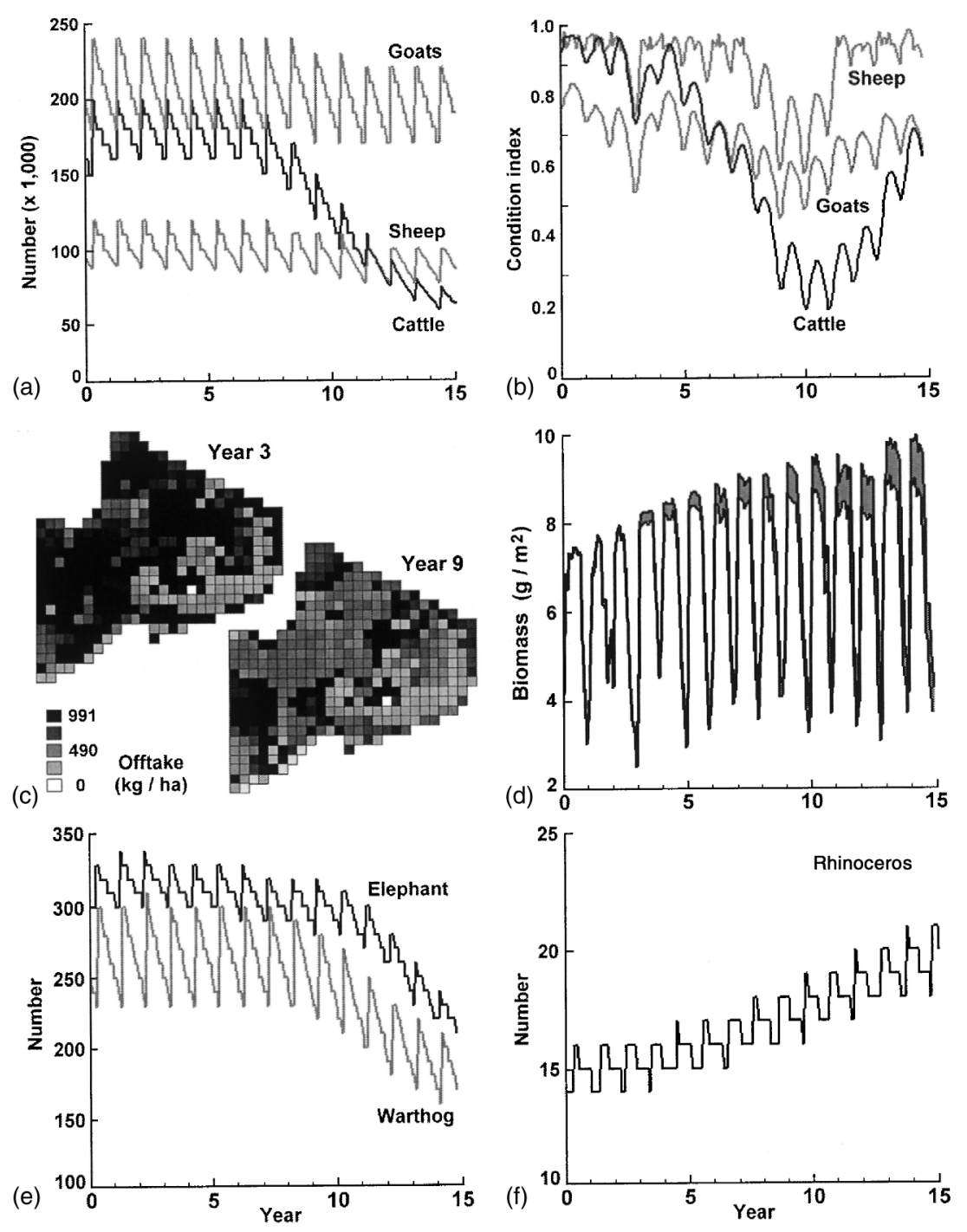

Instead, excess animals were culled, representing livestock sold, slaughtered, or traded by the Maasai, in addition to the number sold or slaughtered in the control model. Animals were culled in proportion to their occurrence in the population.

In one analysis, female calf (i.e. first year) survival was increased from 80 to $87 \%$, male calves from 75 to $82 \%$, and similar changes were made for goats and sheep the relatively high survival rates in the control model exclude losses due to tick-borne diseases, which were modelled separately). Based upon initial population levels, this increased survival of newborns added up to $4.2 \%$ additional cattle (Fig. 4a), 3.8\% goats (Fig. 4b), and 7.5\% additional sheep (Fig. 4c) available for sale.
In similar analyses, the adult survival of livestock was increased by $5 \%$ (e.g. females of cattle from 90 to $95 \%$, goats from 87 to $92 \%$, sheep from 85 to $90 \%$; again, losses to tick-borne diseases were treated separately). Improved survival of adults yielded about $6.8 \%$ additional goats and sheep available for sale during the wettest years (e.g. years 5, 9 and 14), and 6.7\% additional cattle. The birth rates of livestock were increased by $5 \%$, representing improved veterinary practices, and increased forage availability improving animal nutrition. In general, relatively few additional animals were available for sale when birth rates were improved. Finally, the simulated effect of tick-borne diseases was reduced by half in the SAVANNA model. An additional $5.7 \%$ of cattle were available peryear 
(a)
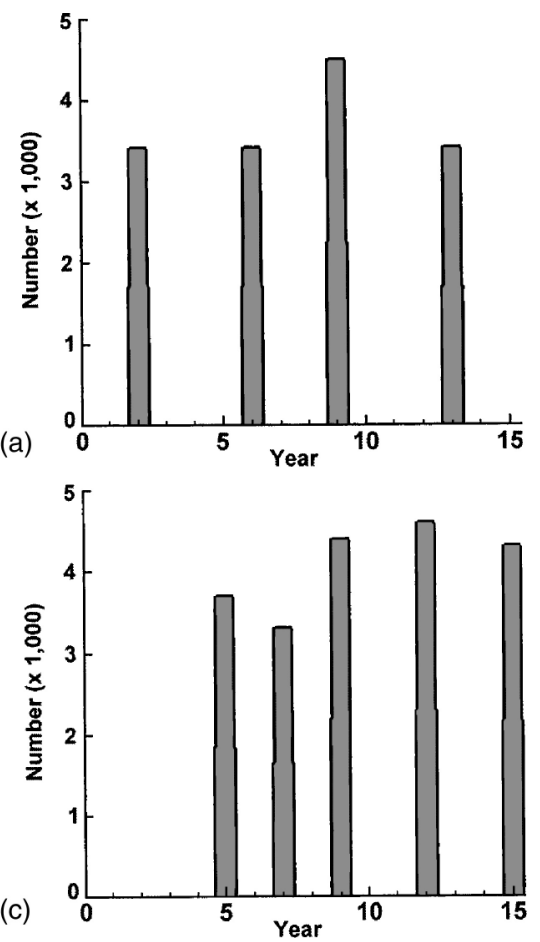

\section{(b)}
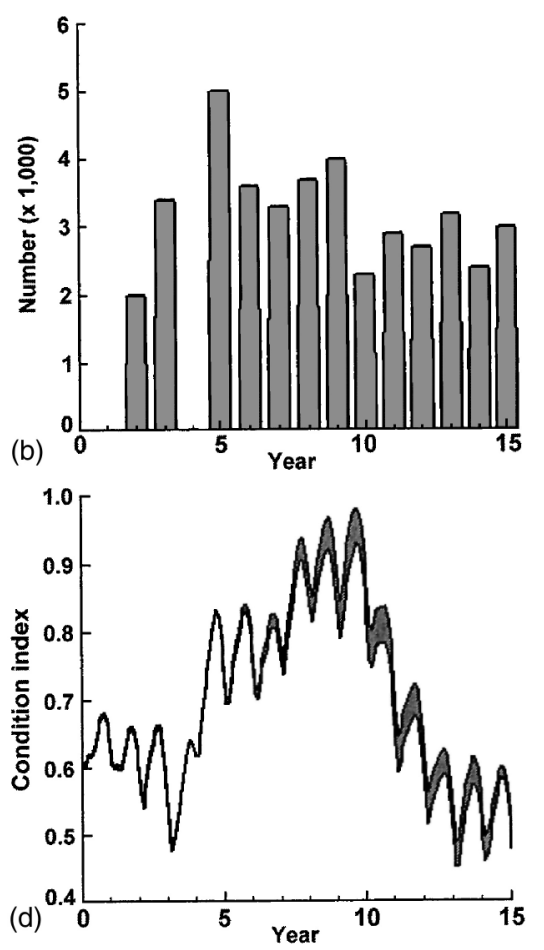

Fig 4 Experiments simulating improved veterinary practices. When the survival rate of first-year cattle, goats and sheep was increased by $7 \%, 3000-4000$ additional cattle were available for sale or slaughter every few years (a), additional goats were available most years (b), and additional sheep were available every few years (c), depending upon long-term conditions. When losses of livestock to disease were reduced, changes in the system (vegetation and wildlife) were small because livestock were culled. For example, condition indices of elephants declined slightly ((d), with the grey area highlighting the decline) for culling or selling, as well as $2.3 \%$ goats each year and $6.3 \%$ sheep every other year.

In these experiments, the animals were removed from the system when a given population level was exceeded. Because of this, relatively few changes occurred in the simulated ecosystem. Small changes in the age structure of the livestock and in the condition of herbivores were observed (e.g. Fig. 4d).

\section{Increased access to grazing lands}

Livestock are unable to graze within NCA craters because of legal restrictions (Runyoro et al., 1995). Herders are also unlikely to graze animals in the south-western portion of the NCA because of a high likelihood of stock theft (Machange, 1997). As mentioned, during the wet season, cattle herders must avoid the short grass plains because of the risk of disease transmission from wildebeest (McCabe, 1995; McCabe, 1997).

When livestock were allowed to graze within NCA craters (Fig. 5a versus Fig. 5b), relatively few additional animals could be supported. However, their condition indices did increase $<5 \%$. Population increases were modest, in part because of the increased likelihood of disease associated with the high, wet craters. Animals restricted to Ngorongoro Crater, such as rhinoceros, declined (Fig. 5c). When livestock were allowed to graze freely in the south-western portion of the NCA (e.g. Fig. 5d), wildlife populations were not strongly affected, except for elephants, which decreased by $22 \%$ (Fig. 5e). After 15 years, 20,000 more cattle $(+19 \%)$ were supported when they were allowed to graze on the plains during the wet season. However, the condition indices of goats and sheep were reduced, indicating that herders of small stock (which are not susceptible to malignant catarrhal fever) avoid competing with cattle by grazing their animals in the midst of wildebeest, which we have observed. Finally, separate simulations with malignant catarrhal fever in-place indicated that $\geq 150$ cattle were lost each week when grazed amongst wildebeest (Fig. 5f).

\section{Water supplies}

Water availability is a critical determinant of the distributions of herbivores in East African conservation areas (Western, 1975). Water maps used in SAvanNa were modified to explore the effects of restoring water sources that were listed as having failed in the past (Aikman \& Cobb, 
Fig 5 Experiments changing areas available for grazing by livestock. Normally cattle are excluded from Ngorongoro Crater ((a), including the white cell, which represents Lake Magadi at the bottom of the crater). Cattle (b) and sheep (not shown) will use the crater, if allowed, whereas goats (not shown) do not favour the habitat. Animals restricted to Ngorongoro Crater, such as rhinoceros (c), decline when livestock use the area. If the threat of stock theft in south-western NCA is reduced, goats will use the area ((d), control versus experiment), but elephants may be excluded (e). Normally, cattle do not use the plains in the wet season because of disease transmission. When that risk is removed, populations increase markedly (not shown), but given the presence of the disease, the number of infections of malignant catarrhal fever would be expected to increase if the short grass plains were used (f) (a)

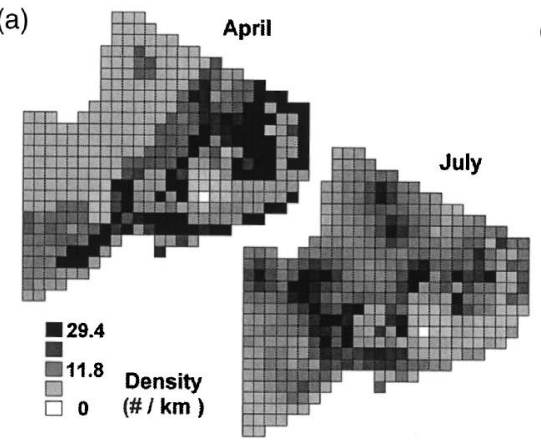

(c)

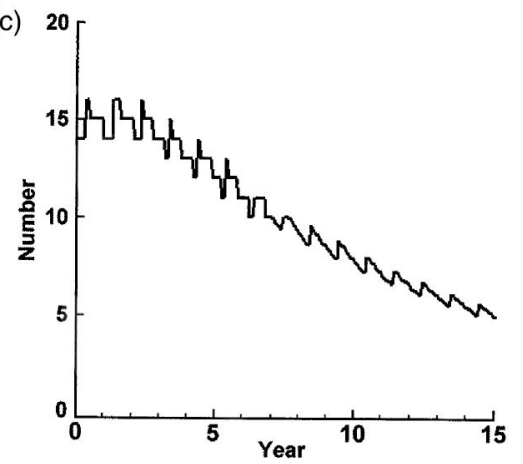

(e)

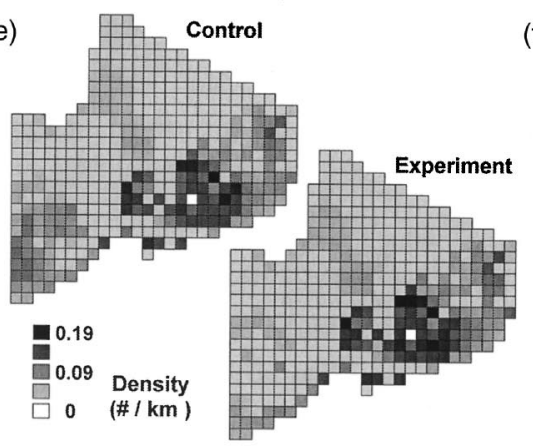

(b)

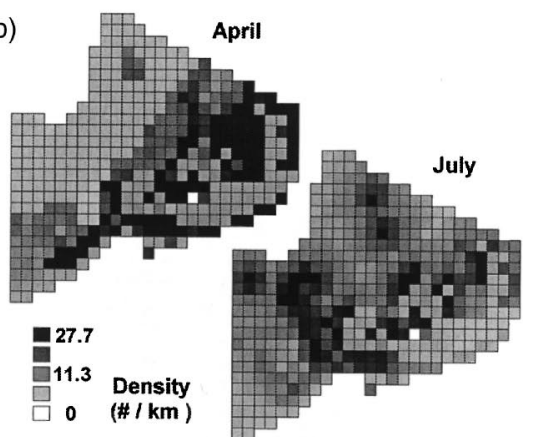

(d)

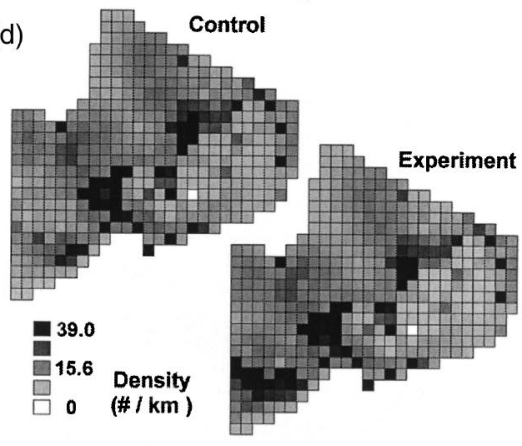

(f)

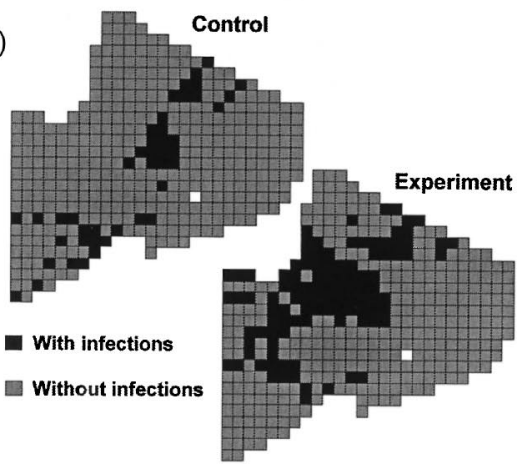

1997). We also examined the contentious issue of water being used by tourist lodges (e.g. Gössling (2001) reported that the average water use by a tourist in Zanzibar, Tanzania, was about 15-fold that of a resident). Any water source within $1 \mathrm{~km}$ of an existing lodge was assumed to be used by lodge residents, and unavailable to herbivores.

When new water sources were added, the mean distance to water during the dry season for all points in the NCA decreased from 10.2 to $9.0 \mathrm{~km}$. The distribution of herbivores and their vegetation offtake were more uniformly distributed (e.g. Figs 6a,b). When some water sources were dedicated to lodges, the mean distance to water did not change markedly (10.2 to $10.5 \mathrm{~km}$ ), affecting only cells near the lodges of the Ngorongoro Crater rim.
The small change was echoed in small changes in range condition and herbivore populations. However, populations such as browsing antelope that inhabited Ngorongoro Crater declined (e.g. Fig. 6c).

\section{Cultivation and human population growth}

Cultivation was banned in the NCA in 1975, but was restored in 1992 to improve food security (McCabe, 1997; Thompson, 1997). Since then, the area under cultivation has increased to about 5000 ha (derived from Smith, 1999) and the human population has increased (Kijazi et al., 1997; NCAA, 1999). We modelled these dynamics in SAvANNA by adding households, with 

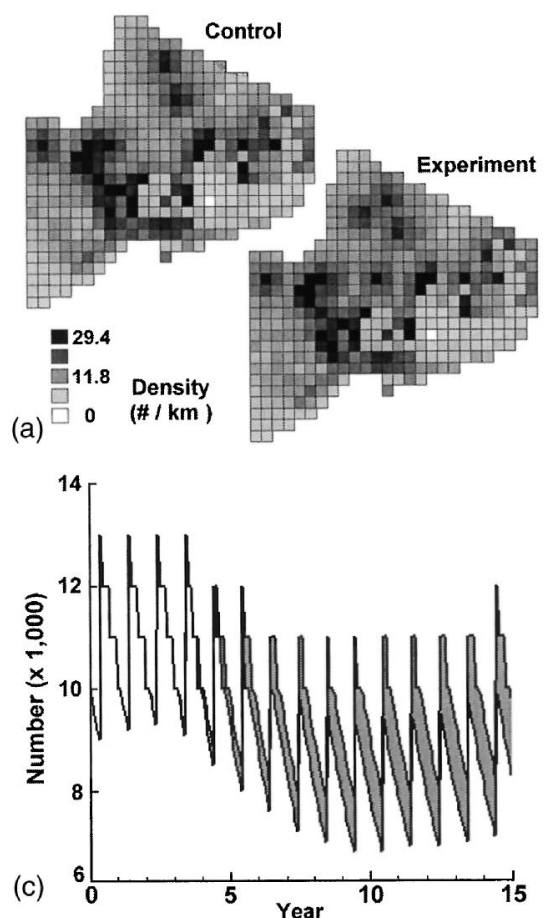

(b)
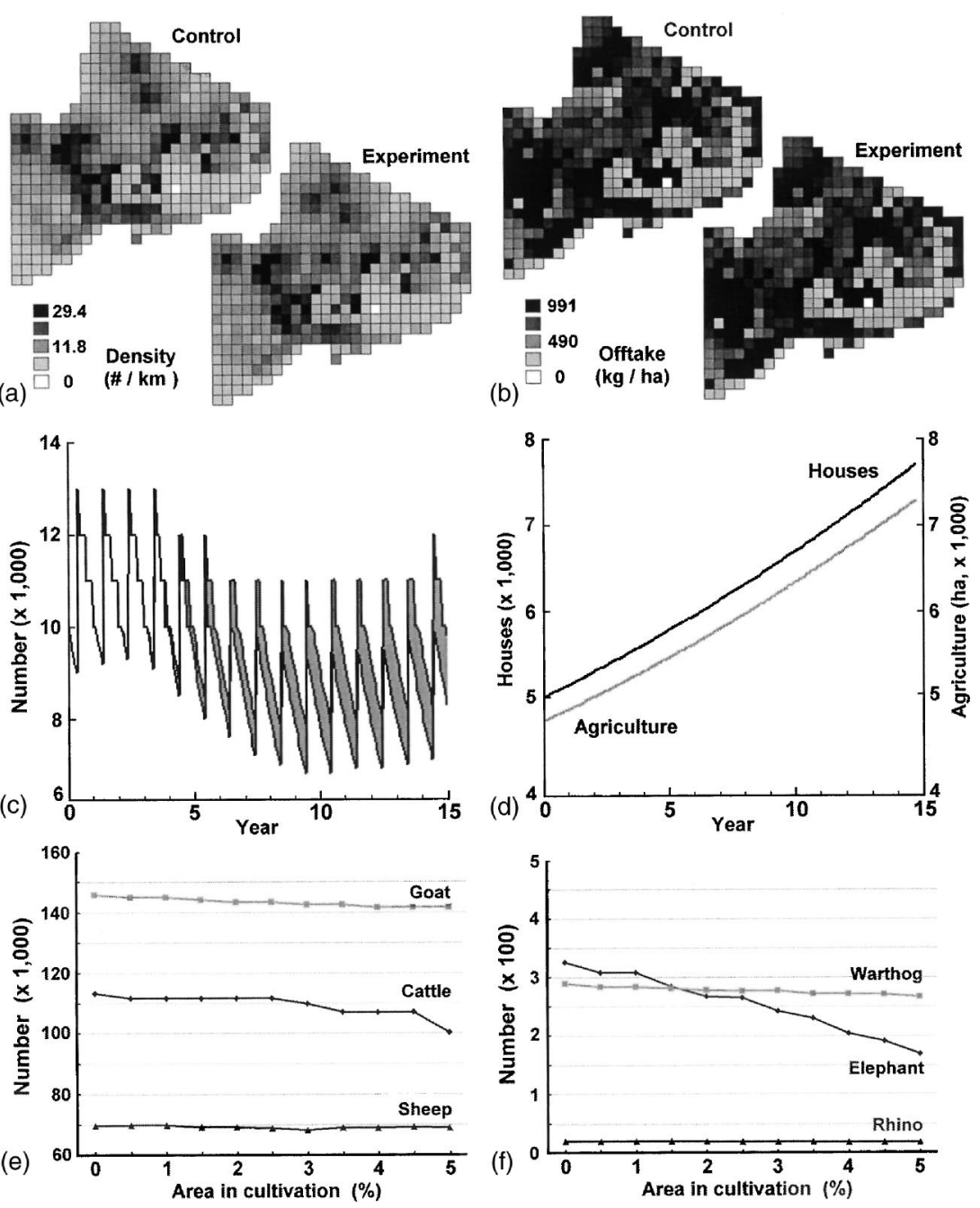

Fig 6 Experiments adding water sources, and increasing households and cultivation in NCA. When additional water sources are added to the system, cattle distribute themselves more evenly across the landscape and cluster about the new sources ((a), comparing control and experiment). Changes in accumulated offtake in the centre of the study area may be seen (b). When water sources are removed for use by tourists in lodges, changes to the system are small but animals within Ngorongoro Crater, such as a portion of the browsing antelope on the system, show declines (c). When the number of households and cultivation increase at 3\% per year, after 15 years there are about 7800 households (d) in NCA, cultivating about 7300 ha, or $0.8 \%$ of the study area. Simulations where cultivation was increased from 0 to $5 \%$ of NCA showed a gradual decrease in livestock similar to most wildlife groups (e), except elephants (f), which declined by $48 \%$ associated cultivation, to the landscape. An annual population growth of $3 \%$ was modelled. In addition, a cultivated area was modelled covering from 0 to $5 \%$ of the $\mathrm{NCA}$, with cultivation added in a way that mirrored the current distribution of the Maasai households (NCAA, 1999).

When human population growth was modelled, the number of households, with ten people each on average (Natural Peoples World/NCAA census summary data), went from 5000 in year 1 to 7702 in year 15. Land dedicated to cultivation went from 4727 ha in year 1 to 7293 ha in year 15 (Fig. 6d). Effects upon herbivores were small, due to the low rate of cultivation [i.e. about $0.8 \%$ of the NCA, although the short grass plains are not arable and comprise about 50\% of the NCA (McCabe, 1997)].
When the cultivated area was increased from 0 to $5 \%$, the responses of the herbivores were variable. In general, however, about $11 \%$ fewer cattle, $3 \%$ fewer goats, and $1 \%$ fewer sheep could be supported when $5 \%$ of NCA was cultivated (Fig.6e). Wildlife populations declined $\leq 16 \%$, except for giraffes, which remained constant, and elephants, which declined by $48 \%$ (Fig. 6 f).

\section{Discussion}

The Savanna modelling system has been used by researchers to conduct analyses yielding precise estimates of effects for a few specific questions, but that is not the intent of the adaptation described. SAvanna was adapted for use by those without modelling expertise, 
and to address a broad range of policy questions (Hilborn et al., 1995). We provide a tool that generates results forming a common foundation upon which interested parties may build a discussion. We start such a discussion here, stemming from the broad array of model experiments conducted.

Possible changes in the distribution of rainfall throughout the year, associated with global warming (Groisman et al., 1999; Mason et al., 1999), may have major impacts on plants and herbivores in the NCA (Ellis \& Galvin, 1994). A slight shift (1\%) in rainfall from the wettest months to the driest months caused large increases in forage availability (e.g. Hall et al., 1995) and herbivore populations. Possible changes in the future not withstanding, results suggest that cattle are near carrying capacity (i.e. a population that can be sustained over a long period), set in part by disease, given their restriction to the midlands and highlands of the NCA during the wet season (McCabe, 1997). If veterinary care and livestock production improve, integrated assessment results strongly suggest that market access will be important with more animals being produced on a system unable to support a large increase in population, the excess must be sold or slaughtered to avoid a population collapse. Homewood \& Rodgers (1991) reviewed difficulties in expanding market access. However, increased commercialism has benefitted the Maasai in Kenya (e.g. Zaal, 1999) as well as some in the NCA (McCabe, 1997).

Opening areas to livestock grazing that are now closed led to mixed results. Small increases in the numbers of livestock may occur, but at the cost of large declines in some wildlife groups, such as elephants in the southern NCA. An exception to this is the restriction of cattle to the midlands and highlands (McCabe, 1997). If an inoculation were developed for malignant catarrhal fever, for example, large areas of NCA would become available for Maasai cattle to graze during the wet season. Results from simulations suggest that ecosystem-level responses to having $0.8 \%$ of the NCA in cultivation are minor. When $5 \%$ of the area was cultivated, larger declines in herbivores occurred, but remained $\leq 16 \%$ for all but elephants. This occurred because the areas most densely populated by Maasai, and therefore, most likely to be under cultivation, were also those most favoured by elephants. Conflicts between the Maasai and elephants can be anticipated. These conflicts must be weighed against improvements in Maasai nutritional status, which is poor compared to the neighbouring Maasai in Loliondo, where there are no restrictions on cultivation [Galvin et al. in press; see Norton-Griffiths (1998) for a review of the costs of conservation to Maasai].

Since the completion of this research, our research team has extended the application to include complex socioeconomic relationships (Thornton, Galvin \& Boone, in press). However, those relationships are not included in the simulations discussed in this paper. The limitations in our modelling methods should be considered when interpreting or applying the results.

To enable non-experts to conduct analyses using the SAVANNA modelling system, a computer program (i.e. SAVVIEW) has been written that provides an interface between the user and the textual parameter files used by SAvAnNA. The Windows-style interface allows users to easily change parameters (e.g. cattle population) and run the model. To date, IMAS tools have been installed in six primary locations in Tanzania and Kenya, and 26 people have received in-depth training on the use of the tools. In an upcoming Global Livestock CRSP project, we will further the use of integrated assessment in East African policy formation.

\section{Acknowledgements}

We thank the entire IMAS team for their assistance in modelling and outreach efforts, especially P. D. Moehlman, J. T. McCabe and R. Reid. Special thanks go to P. D. Moehlman for making the Ngorongoro Ecological Monitoring Program data available for our use. Discussions with P. J. Weisberg improved the model application, and the comments of two anonymous reviewers improved the manuscript. This publication was made possible through support provided by the Global Livestock CRSP (Collaborative Research Support Program) of the Office of Agriculture and Food Security, Global Bureau, United States Agency for International Development, under grant no. PCE-G-98-00036-00 to Coughenour and Galvin. The opinions expressed herein are those of the authors and do not necessarily reflect the views of the US Agency for International Development.

\section{References}

Aikman, D.I. \& Совв, S.M. (1997) Water development. In: Multiple Land-Use: the Experience of the Ngorongoro Conservation Area, Tanzania (Ed. D. M. Thompson). Gland, Switzerland and Cambridge, UK. 
Boone, R.B. \& Krohn, W.B. (2000) Predicting broad-scale occurrences of vertebrates in patchy landscapes. Landscape Ecol. $15,63-74$.

Boshe, J.I. (1997) Wildlife ecology. In: Multiple Land-Use: the Experience of the Ngorongoro Conservation Area,Tanzania (Ed. D. M. Thompson). IUCN, Gland, Switzerland and Cambridge, UK.

Buckley, D.J., Coughenour, M.B., Blyth, C.B., O’Leary, D.J. \& Bentz, J.A. (1993) Ecosystem management model - Elk Island National Park: a case study of integrating environmental models with GIS. In: Proceedings of the Second International Conference on Integrating GIS and Environmental Modelling. National Center for Geographic Information Analysis, University of California, Santa Barbara, CA, USA.

CAmpbell, K. \& Borner, M. (1995) Population trends and distribution of Serengeti herbivores: implications for management. In: Serengeti II: Dynamics, Management, and Conservation of an Ecosystem (Eds A. R. E. SINCLAIR and P. Arcese). University of Chicago Press, Chicago, IL, USA.

Christensen, L., Coughenour, M., Ellis, J., Li, L. \& Price, K. (1999) An integrated assessment of land use and vegetation on the grasslands of Inner Mongolia. Proceedings of the International Rangeland Congress, Townsville, Australia.

Coughenour, M.B. (1985) Graminoid responses to grazing by large herbivores: adaptations, exaptations, and interacting processes. Ann. MO Bot. Gard. 72, 852-863.

Coughenour, M.B. (1992) Spatial modelling and landscape characterization of an African pastoral ecosystem: a prototype model and its potential use for monitoring drought. In: Ecological Indicators (Eds D. H. Mckenzie, D. E. HyATt and V. J. Mcdonald), Vol. 1, Elsevier Applied Science, New York, NY, USA.

Coughenour, M.B. \& ElLis, J.E. (1993) Climate and landscape control of woody vegetation in a dry tropical ecosystem, Turkana District, Kenya. J. Biogeogr. 20, 383-398.

Coughenour, M.B., Ellis, J.E. \& Popp, R.G. (1990) Morphometric relationships and development patterns of Acacia tortilis and Acacia reficiens in Southern Turkana, Kenya. Bull. Torrey Bot. Club $117,8-17$.

Coughenour, M.B., Ellis, J.E., Swift, D.M., Coppock, D.L., Galvin, K., McCABE, J.T. \& HarT, T.C. (1985) Energy extraction and use in a nomadic pastoral population. Science $\mathbf{2 3 0}$, 619-625.

Coughenour, M.B. \& Singer, F.J. (1996) Yellowstone elk population responses to fire - a comparison of landscape carrying capacity and spatial-dynamic ecosystem modeling approaches. In:The Ecological Implications of Fire in Greater Yellowstone (Ed. J. GreenleE). Proceedings of the Second Biennial Conference on the Greater Yellowstone Ecosystem, IAWF, Fairfield,WV, USA.

Ellis, J.E. \& Coughenour, M.B. (1998) The SAVANNA integrated modelling system: an integrated remote sensing, GIS and spatial simulation modelling approach. In: Drylands: Sustainable Use of Rangelands Into the Twenty-First Century. (Eds V. R. Souires and A. E. SIDAhmed). IFAD Series: Technical Reports.
ELLIS, J.E. \& GALVIN, K.A. (1994) Climate patterns and land-use practices in the dry zones of Africa. Bioscience 44, 340-349.

Galvin, J.A., Ellis, J., Boone, R.B., Magennis, A., Smith, N.M. \& LynN, S.J. (in press) Compatibility of pastoralism and conservation? A test case using integrated assessment in the Ngorongoro Conservation Area,Tanzania. In: Proceedings from the Conference on Displacement, Forced Settlement and Conservation. University of Oxford, London, UK.

Gignoux, J., Menaut, J.-C., Noble, I.R. \& Davies, I.D. (1996) A spatial model of savanna function and dynamics: model description and preliminary results. In: Dynamics of Tropical Communities (Eds D. M. Newbery, H. H. T. Prins and N. Brown). Blackwell Science, Oxford, UK.

GössLing, S. (2001) The consequences of tourism for sustainable water use on a tropical island: Zanzibar,Tanzania. J. Environ. Manag. 61, 179-191.

Groisman, P.Y., KarL, T.R., Esterling, D.R., KNight, R.W., Jamason, P.F., Hennessy, K.J., SupPiah, R., PAge, C.M., Wibig, J., Fortuniak, K., Razuvaev, V.N., Douglas, A., Førland, E. \& ZHAI, P.-M. (1999) Changes in the probability of heavy precipitation: important indicators of climate change. Clim. Change 42, 243-283.

Hall, D.O., Ojima, D.S., Parton, W.J. \& Scurlock, J.M.O. (1995) Response of temperate and tropical grasslands to $\mathrm{CO}_{2}$ and climate change. J. Biogeogr. 22, 537-547.

HARRIS, L.D. \& FoWLER, N.K. (1975) Ecosystem analysis and simulation of the Mkomazi Reserve,Tanzania. East AfricanWildl. J. 13, 325-346.

Hilborn, R., et al. (1995) A model to evaluate alternative management policies for the Serengeti-Mara Ecosystem. In: Serengeti II: Dynamics, Management, and Conservation of an Ecosystem (Eds A. R. E. SINCLAIR and P. ARCESE). University of Chicago Press, Chicago, IL, USA.

Hodgkinson, K.C., Ludlow, M.M., Mott, J.J. \& BARuch, Z. (1989) Comparative responses of the savanna grasses Cenchrus ciliaris and Themeda triandra to defoliation. Oecologia 79, 45-52.

Homewood, K.M. \& Rodgers, W.A. (1991) Maasailand Ecology: Pastoralist Development and Wildlife Conservation in Ngorongoro, Tanzania. Cambridge Studies in Applied Ecology and Resource Management. Cambridge University Press, Cambridge, MA, USA.

Kijazi, A., Mкumbo, S. \& Thompson, D.M. (1997) Human and livestock population trends. In: Multiple Land-Use: the Experience of the Ngorongoro Conservation Area,Tanzania (Ed. D. M. Thомpson), pp. 169-180. IUCN, Gland, Switzerland and Cambridge, UK.

KIKER, G.A. (1998) Development and Comparison of Savanna Ecosystem Models to Explore the Concept of Carrying Capacity. $\mathrm{PhD}$ dissertation, Cornell University, Ithica, New York, NY, USA.

LAmbin, E.F., RounsevelL, M.D.A. \& Geist, H.J. (2000) Are agricultural land-use models able to predict changes in land-use intensity? Agric. Ecosyst. Environ. 82, 321-331. 
Ludwig, J.A. \& Tongway, D.J. (1997) Modelling scale-dependent processes and impacts of agricultural disturbances on tropical savanna ecosystems in northern Australia. In: Proceedings of the MODSIM 97 International Congress on Modelling and Simulation (Eds A. D. MCDonald and M. MCALEer). 8-11 December 1997, Hobart,Tasmania, Australia.

Machange, J. (1997) Livestock and wildlife interactions. In: Multiple Land-Use: the Experience of the Ngorongoro Conservation Area, Tanzania (Ed. D. M. Thompson). IUCN, Gland, Switzerland and Cambridge, UK.

Mason, S.J., Waylen, P.R., Mimmack, G.M., Rajaratnam, B. \& HARRISON, J.M. (1999) Changes in extreme rainfall events in South Africa. Clim. Change 41, 249-257.

McCAвE, J.T. (1995) Wildebeest/Maasai interactions in the Ngorongoro Conservation area of Tanzania. Final report submitted to the National Geographic Society. Grant \#4953-93.

McCAвE, J.T. (1997) Risk and uncertainty among the Maasai of the Ngorongoro Conservation Area in Tanzania: a case study in economic change. Nom. Peopl. 1, 55-65.

Mduma, S.A.R., Hilborn, R. \& Sinclair, A.R.E. (1998) Limits of exploitation of Serengeti wildebeest and implications for its management. In: Dynamics of Tropical Communities (Eds D. M. Newbery, H. H. T. Prins and N. Brown). Blackwell Science, Oxford, UK.

Mduma, S.A.R., Sinclair, A.R.E. \& Hilborn, R. (1999) Food regulates the Serengeti wildebeest: a 40-year record. J. Anim. Ecol. 68, 1101-1122.

Minson, D.J., Cowan, T. \& Havilah, E. (1993) Northern dairy feedbase 2001. 1. Summer pasture and crops. Trop. Grassl. 27, 131-149.

Murray, M.G. (1995) Specific nutrient requirements and migration of wildebeest. In: Serengeti II: Dynamics, Management, and Conservation of an Ecosystem. (Eds A. R. E. SINCLAIR and P. ArCESE). University of Chicago Press, Chicago, IL, USA.

Mwalyosi, R.B.B. (1992) Influence of livestock grazing on range condition in Southwest Masailand, northern Tanzania. J. appl. Ecol. 29, 581-588.

NcaA (Ngorongoro Conservation Area Authority). (1999) 1998 Aerial Boma Count, 1999 People and Livestock Census, and Human PopulationTrend Between 1954 and 1999 in the NCA. Report from the Research and Planning Unit, Ngorongoro Conservation Area Authority, Ngorongoro Crater,Tanzania.

NDAWUla-SENyimba, M.S. (1972) Some aspects of the ecology of Themeda trianda. East Afr. Agric. For. J. 38, 83-93.

NoRTON-GRIfFiths, M. (1979) The influence of grazing, browsing, and fire on the vegetation dynamics of the Serengeti. In: Serengeti: Dynamics of an Ecosystem (Eds A. R. E. SINCLAIR and M. Norton-Griffiths). University of Chicago Press, Chicago, IL, USA.

Norton-Griffiths, M. (1998) The economics of wildlife conservation policy in Kenya. In: Conservation of Biological Resources (Eds E. J. Milner-Gulland and R. MACE). Blackwell Science, Oxford, UK.
Perkin, S.L. (1997) The Ngorongoro Conservation Area: values, history, and land-use conflicts. In: Multiple Land-Use: the Experience of the Ngorongoro Conservation Area,Tanzania (Ed. D. M. Thомpson). IUCN, Gland, Switzerland and Cambridge, UK.

Runyoro, V.A. (1998) Research and Ecological Monitoring: Annual Report. Ngorongoro Conservation Area Authority, Ngorongoro Crater,Tanzania.

Runyoro, V.A., Hofer, H., Chausi, E.B. \& Moehlman, P.D. (1995) Long-term trends in the herbivore populations of Ngorongoro Crater,Tanzania. In: Serengeti II: Dynamics, Management, and Conservation of an Ecosystem (Eds A. R. E. SINCLAIR and P. Arcese). University of Chicago Press, Chicago, IL, USA.

Rwambo, P., Grootenhuis, J.G., Demartini, J. \& Mkumbo, S. (1999) Animal Disease Risk in the Wildlife/Livestock Interface in the Ngorongoro Conservation Area of Tanzania. Report to USAID Global Livestock CRSP, Davis, CA, USA.

Sinclair, A.R.E. (1995) Serengeti past and present. In: Serengeti II: Dynamics, Management, and Conservation of an Ecosystem (Eds A. R. E. SinCla AIR and P. ARCESE). University of Chicago Press, Chicago, IL, USA.

Smith, N.M. (1999) Maasai Household Economy: a Comparison Between the Loliondo Game Controlled Area and the Ngorongoro Conservation Area, northernTanzania. MSc thesis, Colorado State University, Fort Collins, CO, USA.

Stronach, N.R.H. \& Mcnaughton, S.J. (1989) Grassland fire dynamics in the Serengeti ecosystem and a potential method of retrospectively estimating fire energy. J. appl. Ecol. 26, 1025-1034.

TEWARI, V.P. (1996) Developing equations for estimating growth parameters of Acacia tortilis (Forsk.) Hayne. Indian For. 122, 1004-1009.

Thompson, D.M., ed. (1997) Multiple land-use: the experience of the Ngorongoro Conservation Area,Tanzania. IUCN, Gland, Switzerland and Cambridge, UK.

Thornton, P.K., Galvin, K.A. \& Boone, R.B. (in press) An agrapasteral household model for the rangelands of east Africa. Agricultural Systems.

Toxopeus, A.G., Bakker, X. \& Kariuki, A. (1994) An interactive spatial modelling (ISM) system for the management of the Amboseli Biosphere Reserve (southeast Kenya). ITC J. 1994, 392-400.

UNESCO (United Nations Educational, SCIENTIFic, AND Cultural Organization) (2000). UNESCO MAB biosphere reserve directory. <http://www.unesco.org/mab/br/brdir/africa/ tanza2.htm >.

USGS (US Geological Survey). (1997) USGS Global Land Information System. EROS Data Center, Sioux Falls, South Dakota. $<$ http://edc.usgs.gov/landdaac/webglis $>$.

USGS (US Geological SuRvey). (1998) Global Land 1-Km AVHRR Project. EROS Data Center, Sioux Falls, South Dakota. <http:// edchttp://www.cr.usgs.gov/landdaac/1KM/1kmhomepage.html>.

Van Horne, B. \& Wiens, J.A. (1991) Forest Bird Habitat Suitability Models and the Development of General Habitat Models. US Department of Interior Fish and Wildlife Service, Fish and Wildlife Research, Washington, DC, USA. 
150 Randall B. Boone et al.

Weisberg, P.J. (2000) Model-Based Assessment of Aspen Responses to Elk Herbivory in Rocky Mountain National Park. Report to US Department of the Interior, Rocky Mountain National Park. Western, D. (1975) Water availability and its influence on the structure and dynamics of a savanna large mammal community. East Afr.Wildl. J. 13, 265-286.

Western, D. \& Gichohi, H. (1993) Segregation effects and the impoverishment of savannah parks: the case for ecosystem viability analysis. Afr. J. Ecol. 31, 269-281.
Wiegand, T., Jeltsch, F., Bauer, S. \& Kellner, K. (1998)

Simulation models for semi-arid rangelands of southern

Africa. Afr. J. Range Forage Sci. 15

$48-60$.

ZAAL, F. (1999) Economic integration in pastoral areas; commercialisation and social change among Kenya's Maasai. Nom. Peopl. 3, 97-114.

(Manuscript accepted 4 July 2001) 